\title{
Wages, Prices and Agriculture: How Can Indian Agriculture Cope with Rising Wages?
}

\author{
Hans P. Binswanger and Sudhir K. Singh ${ }^{1}$
}

\begin{abstract}
Rapid economic growth in India has resulted in rapidly rising rural wages. Using the framework of variable profit functions and household level data, we study econometrically the wage impacts on crop agriculture. Rising wages are associated with decreasing crop output, other things being equal. Crop prices would need to increase by $80 \%$ in the short run to offset the effect of an agricultural wage increase, or by $140 \%$ in the short run to offset rural non-farm wage increases as well. However, because non-land farm assets respond positively to the non-farm wage, in the medium term this increase is reduced to 74\%. During the period of 1999-2008, growth in non-land farm assets, the labour force, education and technology has easily compensated for the wage increase, and probably also for the accelerating wage growth. Focusing on growing these shifter variables is a much better policy option than raising prices that would come at the expense of consumers or taxpayers.
\end{abstract}

Keywords: Crop supply; India; labour demand; prices; wages. JEL classifications: Q1, Q11, Q12, Q13, Q15 Q18.

\footnotetext{
${ }^{1}$ Hans Binswanger is an extraordinary professor at the University of Pretoria, South Africa. Sudhir Singh is at the World Bank, in the Development Research Group, Washington, DC E-mail: ssingh12@worldbank.org for correspondence. The authors thank Hari K. Nagarajan, for his valuable comments on data and Kailash C. Pradhan and J. P. Singh for help in data cleaning and variable constructions. They also thank Andrew Foster at Brown University for his suggestions and comments, seminar participants at ICRISAT, India, Center for Economic and Social Studies, India, and IFPRI Washington DC. All errors are our own. The findings, interpretations and conclusions expressed in this paper are entirely those of the authors not of the institute. They do not necessarily represent the views of the International Bank for Reconstruction and Development/World Bank and its affiliated organisations, or those of the Executive Directors of the World Bank or the governments they represent.
} 


\section{Introduction}

Over the past two decades, the Indian economy has started to grow rapidly. Real wages have begun to rise and during the period of 2007-2012 India experienced a rapid growth in real farm wage of 6.8\% per year since 1991 (Gulati et al., 2014). As Indian economic growth accelerates again, wages are likely to rise faster than before and, all other things being equal, the farm sector might experience a profit squeeze. In addition, farm sizes have been declining, adding another element to the profit squeeze. As a consequence, farm income could be squeezed and the growth of food supplies could decelerate.

During the periods of rapid growth and major structural transformation, similar sequences of events arose in all developed and developing countries, including in China and other rapidly growing countries of Asia. Structural change leads to a decline in the shares of output and labour in the agricultural sector and an increase in the productivity gap, until the economies mature, and they then start to converge at very low levels (Timmer, 2009). Rural to urban migration and rising wages lead to complex adjustments in the farm sector and to intricate policy dilemmas. There are a number of ways to compensate for rising real farm wages: farmers can replace labour by mechanisation; they can exit agriculture and make room for growth of the remaining farms; they can diversify into higher valued commodities whose demand grows as a consequence of the income growth and urbanisation associated with structural change; governments can invest more in productivity enhancing research, irrigation, infrastructure and education; finally, governments can raise food prices to support farm incomes, or they can increase imports of tradable agricultural commodities to make up for possible decline or slower growth in food supplies. ${ }^{2}$ All these responses occurred in various combinations across OECD countries and rapidly growing developing countries during their periods of rapid structural change.

\footnotetext{
${ }^{2}$ Parikh et al. (2016) consider the possibility of larger imports of food grains and show that under the scenario of rapid growth of imports, agricultural productivity could not be accelerated. By 2025, under the assumptions, the country would have to import 60 to 100 million tons of food grains, which is an unlikely option to be accepted by the government. Many horticulture and livestock products are perishable and therefore import options are more limited than for food grains. These products are included in the analysis.
} 
In the OECD countries, price and trade interventions became prevalent during the transformation, reflecting the political power of and support for farmers. It was not believed, or deemed politically acceptable and credible, that this could be achieved via productivity growth, diversification of agricultural production or growth in farm size alone, and therefore all countries experiencing structural transformation have intervened to support agriculture by raising producer prices or subsidising producers, such as the rapidly growing input subsidies in China.

For commodities that are imported, prices could be supported via a combination of increased support prices and import tariffs, for exported crops via export subsidies and for domestically produced crops via price interventions and public stocks. These are the policies that OECD countries have pursued in response to rapid economic growth and structural change, especially after World War II. These have led to the high rates of protection for their agriculture sectors (Anderson et al., 2010), at the expense of consumers and tax payers. In addition, the downward pressure on international agricultural prices also hurt world exporters and their development potential, leading to surpluses that were disposed of by subsidising exports, further disrupting markets. In this way, high protection rates have accelerated agricultural growth in the OECD countries at the expense of the agricultural sectors of developing countries. Since the Uruguay round of WTO negotiations, the high and low income countries have tried to overcome these adverse legacies of the OECD wage booms. However, progress has been limited, as tariff bindings beyond which tariffs may not rise have been set at very high levels (Anderson, 2009), which have only declined after the Uruguay Round. In recent years, the EU and other OECD countries have been changing agricultural support policies to resolve the predicaments they created. Typical policies have been to reduce or eliminate agricultural price subsidies or protection, and replace them by fixed payments and other measures of support in the green box of the WTO. However, progress in doing so has been varied among the different regions and countries. There are, therefore, many reasons why India should consider very carefully whether to engage in such a set of policies, only to find itself with similar adverse legacies.

The rapid economic growth in the Indian economy that started in the early 1990s has resulted in similar policy dilemmas, but structural change has differed significantly from that observed in the past in OECD countries or China (Binswanger, 2013). The economic growth has not been 
associated with a rise in the share of manufacturing, and therefore rural-urban migration of unskilled or low-skilled workers continued to be slow. Higher skilled individuals had better prospects and moved primarily into the information technology sector and other modern services. Therefore the urban economy provided rapidly rising opportunities for college graduates and other skilled workers, but not for the majority of the rural population. Fortunately, the rural non-farm sector started to grow very rapidly, particularly the construction sector, and became the single most important destination for the shift of labour from agriculture to nonagriculture that normally accompanies structural transformation.

Even with slow rural-urban migration, agricultural wages started to grow in the early 1990s. The factors that contributed to the rise were accelerating economic growth, the growth of the rural non-farm sector, the rapid expansion of government programmes for rural infrastructure, and the expansion of social rural programmes. Of these the Mahatma Gandhi National Rural Employment Guarantee Act (MGNREGA), under which public employment expanded rapidly, is considered to have increased wages and the purchasing power of rural labour force (Binswanger, 2013; Deininger et al., 2016; Imbert and Paap, 2015). Although the wage impact of MGNREGA has been significant, Gulati et al. (2013) have shown that since the early 2000s the contribution of the growth of the economy to wage growth has been 4 to 6 times higher than that of the MGNREGA implementation. It is therefore clear that economic growth, especially in the construction and rural non-farm sectors, and the expansion of public sector rural expenditures were far more important determinants of the observed increases in rural wages than the MGNREGA (Gulati et al., 2013).

We use a framework of an output supply and four variable factor demand equations that are consistent with a variable profit functions. We also estimate equations explaining investments into three quasi-fixed factors. Our variable inputs include hired and family labour flows, fertilisers and hired machinery days, while the quasi-fixed factors of production include the family labour stock, land owned and non-land farm assets. These are an aggregate of farm machinery and implements (including irrigation equipment), livestock, and other assets, such as farm buildings. Additional shifter variables include the village tractor density as a proxy for the availability of machines that can be rented. The wages considered for this study are the 
agricultural wage, the rural non-farm wage and the urban wage, with the impacts on output supply, input demand and investment in quasi-fixed factors estimated separately for each wage. The agricultural and rural non-farm labour market are closely related. Most migration in India takes place within states, the states can be considered to have integrated labour markets in which the growth of the state-level urban wage influences the agricultural and the non-farm wages. Land owned, the family labour force, and agricultural assets are also treated as endogenous, and are taken into account in the medium- to long-run elasticities of aggregate output with respect to prices and wages. However, our data cover only two years - 1999 and 2007 - and it is unlikely that capital and the family labour force fully adjusted to price and wage changes within these periods. The resulting final elasticities, therefore, should be considered as intermediate elasticities.

The output supply and input demand equations also include a limited number of shifter variables such as the number of tractors available in the village and the village adoption rate of high yielding varieties. As emphasised by Mundlak (2000), much of the technical change in agriculture is likely to be embodied in non-land farm assets, tractors and seed. ${ }^{3}$ What is not included in the analysis is any technical change that is not embodied in these factors. In addition, there are other potential shifter variables such as roads or access to markets and banks, but in our analysis these variables generally were not significant, even though in the literature based on district data they were quite important (Binswanger et al., 1985).

Studies of growth and structural transformation, including the agricultural transformation that stems from it are normally conducted with aggregate data at national or sub-national levels. In this study, however, we use household level micro data. More specifically we use two rounds of a national sample of Indian rural households. Micro data provide many advantages over the use of macro data at national or state levels. They allow us to estimate all the parameters needed for

\footnotetext{
${ }^{3}$ The non-land farm assets include the tractors of the few farmers who buy them, but the adoption of tractors and the associated machines is mostly done through rental markets. The tractor density in the village is a proxy for the supply of these services.
} 
this analysis from micro data, and therefore avoid aggregation biases. In addition, the micro-data allow for the separate analysis of the impact of higher farm and non-farm wages on hired and family labour, which is almost impossible with macro data. Thus, it is not possible when using macro data to analyse the consequences of the rapid growth of the rural non-farm sector and associated wages, which is particularly relevant for India. While aggregate data on the stock of farm machinery exists in the quinquennial agricultural censuses, there are no data on the use of these machines via machine rental, which is important because most farmers in India do not own the machines. The micro data also allow for the estimation of all the needed trends in the variables of interest from the data itself, i.e. changes in output and inputs, output and input prices and investment in farm assets.

The remainder of this paper is organised as follows. Section 2 reviews the relevant literature. Section 3 presents the data and descriptive results. Section 4 describes the analytical framework. Section 5 deals with the estimation strategy, endogeneity issue in the estimation, and discusses the limitation of our approach. The empirical results are presented in section 6 , and section 7 provides a summary and conclusions.

\section{Related Literature}

To date, there is a limited literature evaluating the impact of rising wages on aggregate agricultural or crop output using household level panel data, mainly because the data have not been available. Otsuka et al. (2013) used panel data from 107 countries between 1980 and 2010 to evaluate the impact of rising wages on the use of tractors, labour and cereal yields, and then evaluated the impact of yield growth on food self-sufficiency. They found a positive impact of wage increases on machinery use for countries that have bigger farm sizes while there was no impact for countries with smaller farm sizes. Further they found that labour use was negatively affected by rising wages for the smaller households, which perhaps indicated a response to migration to the off-farm sector or to urban areas. They found that the cereal yield responds negatively to a rise in wages, with an elasticity of -0.17 , the same order of magnitude as our estimate of the elasticity of aggregate crop output that also contains non-cereal crops that we estimate in this paper. 
Using household level panel data from Indonesia, Yamauchi (2016) finds that increases in both agricultural and non-agricultural wages have increased the cultivated area and machine use. Wang et al. (2016) find similar results for China. Jacoby (2016) uses a general equilibrium model and district level data to analyse the impact of rising food prices on agricultural and nonfarm wages in India and finds that wages respond quickly to rising food prices, thus making landless workers better off. This would make price rises more innocuous in terms of the welfare of the rural poor, but a similar effect would also be needed for urban workers.

Historically, estimated elasticities for short-run aggregate supply from agriculture with respect to its price have been generally very low (Binswanger, 1989). A key issue in the literature has been the question of the size of the long-run elasticity of aggregate crop output with respect to its price. Studies that used cross-sectional data within countries or across countries typically found very high long-run elasticities. For example, Peterson (1979) analysed data from 53 different countries from the 1960s and found elasticities of aggregate cereal yields per acre with respect to price of 1.27 to 1.66. However, such cross-sectional studies suffer from severe unobserved variable biases. Rao's (1989) literature review found that estimates of long-run elasticities, using time series studies within countries with lagged dependent variables, ranged from 0.1 to 0.3 , although Reca (1976) found that such estimates ranged from 0.42 to 0.53 for Argentina, a country with abundant agricultural resources. Most importantly for us, Krishna (1982) found that the long-run elasticity of aggregate crop output with respect to its price was 0.3 , at the upper end of the range suggested by Rao (1989).

Mundlak (2000) and others have challenged using the lagged endogenous variable approach, arguing that it does not fully capture the long-run effect of price on capital investment into agriculture and labour migration. McGuirk and Mundlak (1991) used a general equilibrium model for the Indian state of Punjab for the period of 1960 to 1979 with endogenous capital accumulation in agriculture, as well as inter-sector migration and land expansion. An upward shift in the prices led to an adjustment of the desired stocks of capital, labour and land. Due to constraints on investment, inter-sector migration and land expansion, these stocks adjusted gradually. They estimated these three equations econometrically and built the results into the 
general equilibrium model. The authors estimated a one-year elasticity of aggregate agricultural output (including livestock output) for Punjab agriculture. The short-run price elasticity of agricultural output (including livestock) is near zero, while the response after 20 years rose to 0.18. Mundlak et al. (1988) also used a general equilibrium model for Argentina with the accumulation of agricultural capital and the inter-sector allocation of labour being endogenous and econometrically evaluated. They estimated a one-year elasticity of aggregate agricultural output (including livestock output) to price of 0.07 . The progressive adjustments to the desired capital stocks, land and labour force were slow, but persisted in the long run. Their price elasticity increased to 0.36 in 5 years, which is the period closest to the 7 -year period we use here. As shown below, their price elasticity is slightly higher than the long-run estimate of 0.28 that we obtain, which may be because land use in Argentina could expand over the entire period of analysis, while it cannot expand in India. The elasticity rose to 0.42 over 10 years. A persistent response of the actual capital stock, the labour force and land resulted in an increase in the price elasticity to 1.78 after 20 years.

Consequently, we treat land owned, the family labour force, and non-land agricultural assets as endogenous, which are taken into account in the medium- to long-run elasticities of aggregate output to prices and wages. However, our data covered only two years (1999 and 2007) and it is unlikely that capital and the family labour force fully adjusted to price and wage changes within these periods. The resulting final elasticities, therefore, will be considered as intermediate elasticities. Our literature review has not found any results of the impact of rural wages on aggregate agricultural or crop output.

\section{The Data and Descriptive Statistics}

\subsection{Data}

We use the last two rounds of the Rural Economics and Demographic Surveys (ARIS-REDS) conducted by the National Council of Applied Economic Research New Delhi. The survey covers 238 villages from 17 major states in India, consisting of village and household databases. The first round of the survey of complete village and household information is available in the 1971 Additional Rural Incomes Survey (ARIS), which included 4,527 households in 259 villages; this was meant to be representative of the entire farm population of India, including 
landless workers, residing in 17 major states. ${ }^{4}$ All of the surviving households in the 1982 survey were surveyed again in 1999 and 2007. ${ }^{5}$ The sample included all split-off households residing in the village, plus a small random sample of new households. Because of household division and the households added in 1999, the number of households in the 1999 round increased to 7,474. The split households of the 2007 round were re-aggregated to the parent household in 1999. The balanced panel dataset that encompassed the 1999 and 2007 rounds of the survey comprised 5,725 households.

Each round of the survey had three components. The first component was the village community questionnaire, which had detailed information on the village economy, governance, village finances, employment, history of the village, etc. This information was canvassed from a range of sources from both within and outside of the village. The second component was a listing of the village households. It located, identified and collected information on heads of household, split-offs and out-migration. Households in the listing sheets of each successive round can be traced across rounds. These first two components were collected in 2007. The third component consisted of the household questionnaires, which were mainly canvassed in the agricultural year 2007-2008, with some late questionnaires added in the subsequent two years. The relevant time interval for most households was eight years. Nominal prices were deflated by the state level consumer price indices for rural agricultural labour. ${ }^{6}$

Crop output price is a Fisher index, generated at the village level using various crops grown in the village. The wage rates are the village wage rate, reported directly in the village questionnaire. Fertiliser use is the sum of the kilograms of nitrogen, phosphorus and potassium

\footnotetext{
${ }^{4}$ The original sampling frame was a stratified design that included the following: (i) One district in each state that was part of the Intensive Agricultural District Programme (IADP), an extension and input provision programme placed in areas thought to have high potential for crop productivity growth; (ii) A random sample of other districts. There are 100 districts represented in the 1971 ARIS.

${ }^{5}$ The survey was done in a different point in time. It started in 2006 with listing all households in a village thus known as REDS2006. We use year 2007 for REDS2006 throughout the text because, other than the household listing data, the households in REDS were surveyed during the period of 2007-2008.

${ }^{6}$ Since the survey was rolled out over more than two years, we matched the survey period in each state with the average of the respective months of the CPI for rural agricultural workers.
} 
applied, as well as organic fertiliser, while the price is a village-level weighted average. The data for machine rental are in days, while the machine rental rate is the village level rate of hiring machines such as tractors. Land and inherited land refer to the owned area of the household, while the labour force includes all individuals in the household between age 14 and 64 years old. Non-land farm assets are an aggregate of draft and milk animals, farm machinery and implements, and farm buildings. ${ }^{7}$ Education is measured as the average years of schooling of the members of the labour force. The number of tractors, the proportion of crops that are covered by high yielding varieties (HYV) and Panchayat welfare expenditures come from the village schedule. These are the expenditures on a number of government welfare programmes controlled by the village government, the Panchayat. It was included as it could possibly affect labour supply and wages. Household splits are the probability of a household dividing residence and total assets during the period 1999-2007, which we predict following Foster and Rosenzweig (2002). ${ }^{8}$

\subsection{Descriptive statistics}

Tables 1 and 2 summarise our data. ${ }^{9}$ Between the two rounds, the agricultural years 1999/2000 and 2007/2008 household size decreased at the annual rate of $-2.23 \%$, just a little less than the decrease in area owned per household at $-2.70 \%$ (Table 1). Therefore, the number of household members per owned acre, rather than increasing sharply, increased only moderately at $0.75 \%$, a statistically insignificant increase. The number of workers per owned acre increased at the faster

\footnotetext{
${ }^{7} \mathrm{We}$ used the prices of these assets in 1999 to estimate a real value. It would have been better to estimate user costs, but we did not have data on the age of the assets and therefore could not estimate their remaining life, even if we had assumed a rate of depreciation. We are not aware of studies of such rates for Indian agriculture

${ }^{8}$ Variables used in prediction of household splits are head's age, square of head's age, land owned, mean schooling of the household, maximum schooling of household, variance in schooling, number of male children, number of female children, income growth between 1999-2007, interaction of income growth and schoolings, number of claimants, number of departed daughters and number of departed sons. All variables except growth in income are from 1999 data. Regression results are included in the online Appendix.

${ }^{9}$ A more detailed description of the agricultural data used in this paper, their transformations, and the trends they show over the eight years is provided in Binswanger et al. (2014).
} 
rate of $1.3 \%$ per annum, suggesting that the proportion of working age adults in the households increased. The share of the workforce in agriculture declined at the annual rate of $1.3 \%$, while the share employed outside agriculture grew by $1.4 \%$. Household labour was reallocated from agriculture to the non-farm sector, in line with national trends. The shift from farm to non-farm employment in India accelerated in the 1990s and continues today (Binswanger, 2012).

The slight increase in farm profits per acre with the rising wages in the non-farm sector and the reallocation of labour to that sector combined to produce an increase in per capita income of $8.9 \%$. A large share of the increase of cultivators' incomes came from increases in non-farm selfemployment income, the most rapidly growing component of famers' income (Binswanger, 2012). The share of workers that were in education more than doubled, which indicated the increased importance of education to households.

In India most farms are too small to own their own modern machinery such as tractors etc. They therefore mechanise primarily by increasing their machine rentals, in this case at the annual rate of $2.43 \%$. However, as a proxy for the availability of machines, the tractor density in the village is used, even though tractors may also be hired from outside the village. Village tractor density rose at a rate of $2.34 \%$, almost twice as fast as the HYV coverage in the village. In many regions of India, the coverage of HYV has reached saturation point, while during the decades of the 1990s and 2000s land preparation by tractors virtually replaced that of draft animals in India. Land preparation and threshing are power-intensive and tend to be mechanised even if wages are low, while control-intensive operations such as rice transplanting, weeding, sowing and harvesting of crops is only mechanised as wages start to rise (Binswanger, 1986). It is only in the last 10 to 15 years that rising rural wages have driven the mechanisation of control-intensive operations. The pattern of mechanisation is similar to China, and in both countries harvest combines for rental have become common despite the small plot sizes. To reap their economies of scale, the combines are moved from region to region, following the harvesting seasons.

The non-land farm assets include all owned machinery and tools, irrigation tools and infrastructure, owned livestock, of which the most important are milk animals and decreasingly 
draft animals, orchards and farm buildings. Investment in these non-land farm assets grew rapidly at 5.8\% per annum over the period 1999-2007.

The aggregate crop output and real crop prices rose at the annual rates of $1.17 \%$ and $1.48 \%$ (Table 2) which means that total revenue rose by more than the total real cost of production, leaving a profit growth of $0.60 \%$ per annum. Family labour input was more than twice as large as the hired labour input, but hired labour grew almost twice as fast as family labour, at an annual rate of $5.22 \%$. This rapid growth in the use of hired labour occurred notwithstanding the rise in agricultural wages at an annual rate of $0.9 \%$, and despite the rapid rise in machine rental. Supported by our other results, this implies that the increase in hired labour compensated for family labour moving into the non-farm sector and to education. This was partly a consequence of the faster growth of the non-farm wage compared to the agricultural wage. The urban wage, which grew at only $1.37 \%$ per annum, suggests that the incentives for the labour force to migrate to urban areas were far lower than those to shift to the non-farm activities without having to migrate. This is consistent with the findings of Binswanger (2013), who showed that the main driver of employment in India has been the rural non-farm sector. Finally, (Table 2) the total per capita income of the households in the survey grew at an annual real rate of $8.9 \%$ over this period, a rate outstripped only by the annual increases in welfare spending and occupations mainly in education (Table 1). 
Table 1

Key characteristics of farm households and villages

\begin{tabular}{|c|c|c|c|c|}
\hline Variables & 1999-2000 & 2007-2008 & $\begin{array}{l}\text { Annual } \\
\text { growth } \\
\text { rate } \\
(\%)\end{array}$ & $t$-test \\
\hline \multicolumn{5}{|l|}{ Characteristics of households } \\
\hline Household size & $\begin{array}{c}7.01 \\
(3.83)\end{array}$ & $\begin{array}{c}5.76 \\
(2.81)\end{array}$ & -2.23 & $* * *$ \\
\hline Household size/owned area & $\begin{array}{c}3.15 \\
(2.83)\end{array}$ & $\begin{array}{c}3.34 \\
(3.79)\end{array}$ & 0.75 & \\
\hline Education of household head & $\begin{array}{c}4.16 \\
(3.62)\end{array}$ & $\begin{array}{c}5.25 \\
(4.57)\end{array}$ & 3.28 & $* * *$ \\
\hline Average education of labour force & $\begin{array}{c}4.62 \\
(2.83)\end{array}$ & $\begin{array}{c}5.77 \\
(3.79)\end{array}$ & 3.11 & $* * *$ \\
\hline Workers per owned acre & $\begin{array}{c}1.82 \\
(3.42)\end{array}$ & $\begin{array}{c}1.99 \\
(5.16)\end{array}$ & 1.17 & $*$ \\
\hline Of which in agriculture & $\begin{array}{c}0.76 \\
(1.35)\end{array}$ & $\begin{array}{c}0.69 \\
(1.61)\end{array}$ & -1.15 & \\
\hline Of which in non-agriculture & $\begin{array}{c}0.94 \\
(2.41)\end{array}$ & $\begin{array}{c}1.03 \\
(2.83)\end{array}$ & 1.20 & \\
\hline Of which in other (mainly students) & $\begin{array}{c}0.12 \\
(0.47)\end{array}$ & $\begin{array}{c}0.25 \\
(1.53)\end{array}$ & 13.54 & $* * *$ \\
\hline \multicolumn{5}{|l|}{ Land and non-land farm assets } \\
\hline Land owned (in acres) & $\begin{array}{c}6.07 \\
(8.76)\end{array}$ & $\begin{array}{c}4.86 \\
(6.76)\end{array}$ & -2.49 & $* * *$ \\
\hline Net operated area (in acres) & $\begin{array}{c}5.98 \\
(8.41)\end{array}$ & $\begin{array}{c}4.79 \\
(6.90)\end{array}$ & -2.48 & $* * *$ \\
\hline Value of non-land farm assets & $\begin{array}{c}7,080.80 \\
(34,846.96)\end{array}$ & $\begin{array}{c}10,707.66 \\
(24,484.62)\end{array}$ & 6.40 & $* * *$ \\
\hline Village tractor density (number/100 acres) & $\begin{array}{c}16.75 \\
(10.06)\end{array}$ & $\begin{array}{c}19.88 \\
(18.34)\end{array}$ & 2.34 & $* *$ \\
\hline Village adoption rate of HYV & $\begin{array}{c}0.52 \\
(0.47)\end{array}$ & $\begin{array}{c}0.57 \\
(0.46)\end{array}$ & 1.20 & $* * *$ \\
\hline Panchayat welfare expenditures (' 000 ') & $\begin{array}{c}186.6 \\
(465.2)\end{array}$ & $\begin{array}{c}381.9 \\
(727.2)\end{array}$ & 13.05 & $* * *$ \\
\hline No. of observations & 2944 & 2944 & & \\
\hline
\end{tabular}

Notes: Standard deviations are in parentheses. Values of non-land farm assets are in per acre, while the number of tractors is recorded per 1,000 acres. All values and prices are deflated to 1999 prices using state level price index for agricultural labourer. 
Table 2

Summary statistics of household income, outputs and inputs, prices and wages

\begin{tabular}{|c|c|c|c|c|}
\hline Variables & 1999-2000 & $2007-2008$ & $\begin{array}{c}\text { Annual } \\
\text { growth rate } \\
(\%)\end{array}$ & $t$-test \\
\hline Aggregate crop output per acre & $\begin{array}{c}12,185.57 \\
(25,290.59)\end{array}$ & $\begin{array}{c}13,326.76 \\
(10,754.21)\end{array}$ & 1.17 & $* * *$ \\
\hline $\begin{array}{l}\text { Price index of aggregate crop } \\
\text { output }\end{array}$ & $\begin{array}{l}1.00 \\
(0.00)\end{array}$ & $\begin{array}{c}1.12 \\
(0.36)\end{array}$ & 1.48 & $* * *$ \\
\hline Total cost of production per acre & $\begin{array}{c}4,967.01 \\
(4,969.87)\end{array}$ & $\begin{array}{c}5,884.38 \\
(4,031.41)\end{array}$ & 2.31 & $* *$ \\
\hline Total profit per acre & $\begin{array}{c}7,303.28 \\
(60,573.64)\end{array}$ & $\begin{array}{c}7,656.38 \\
(112,634.50)\end{array}$ & 0.60 & $*$ \\
\hline Hired labour days per acre & $\begin{array}{c}14.38 \\
(21.88)\end{array}$ & $\begin{array}{c}20.38 \\
(27.24)\end{array}$ & 5.22 & $* * *$ \\
\hline Family labour days per acre & $\begin{array}{c}40.49 \\
(68.16)\end{array}$ & $\begin{array}{c}47.46 \\
(79.59)\end{array}$ & 2.15 & $* * *$ \\
\hline Agriculture wage per day & $\begin{array}{c}45.52 \\
(17.37)\end{array}$ & $\begin{array}{c}48.77 \\
(14.68)\end{array}$ & 0.90 & $* *$ \\
\hline Non-agricultural wage per day & $\begin{array}{l}56.25 \\
(19.65)\end{array}$ & $\begin{array}{c}65.99 \\
(18.82)\end{array}$ & 2.16 & $* * *$ \\
\hline Urban wage per day & $\begin{array}{l}105.12 \\
(29.96)\end{array}$ & $\begin{array}{l}116.65 \\
(27.15)\end{array}$ & 1.37 & $* * *$ \\
\hline Fertiliser cost per acre & $\begin{array}{c}176.59 \\
(146.84)\end{array}$ & $\begin{array}{c}176.94 \\
(183.81)\end{array}$ & 0.02 & \\
\hline Fertiliser price $(\mathrm{Rs} / \mathrm{Kg})$ & $\begin{array}{c}9.39 \\
(10.31)\end{array}$ & $\begin{array}{c}8.94 \\
(21.25)\end{array}$ & -0.60 & \\
\hline Share of household uses machine & $\begin{array}{c}62.04 \\
(42.11)\end{array}$ & $\begin{array}{c}74.10 \\
(38.90)\end{array}$ & 2.43 & $* * *$ \\
\hline Machine rental per day & $\begin{array}{l}149.58 \\
(95.64)\end{array}$ & $\begin{array}{l}206.57 \\
(88.81)\end{array}$ & 4.76 & $* * *$ \\
\hline Total per capita income & $\begin{array}{c}10,570.63 \\
(21,477.68) \\
\end{array}$ & $\begin{array}{c}18,098.20 \\
(124,258.60) \\
\end{array}$ & 8.90 & $* * *$ \\
\hline No. of observations & 2,944 & 2,944 & & \\
\hline
\end{tabular}

Notes: Standard deviations are in parentheses. All values and prices are deflated to 1999 prices using state level price index for agricultural labourers. Annual growth rate in agriculture wage is $1.80^{\mathrm{a}}$ per annum. ${ }^{a}$ Average of agricultural and non-farm wage weighted by the mean shares of hired and family labour in total labour over the period 


\section{Conceptual Framework}

\subsection{Output supply and input demand}

The structure of a farmer's choice about the output and variable input levels can be defined by a variable normalised profit function in terms of the output and input prices, and in terms of household and village characteristics. The profit concept used in this framework is the value of total production, net of all variable inputs. These profits are the agricultural returns to the quasifixed factors, family labour, land and non-land farm assets (i.e. it is the return to the household's endowments). ${ }^{10}$ Family labour can be allocated to the farm or rural non-farm sector, therefore it also enters as a flow variable among the variable factors.

The farmer maximises profits with respect to the aggregate output price $\boldsymbol{p}$ and the variable input price $\boldsymbol{w}$. His or her constraints include the quasi-fixed factors of family size, land owned, and the stock of non-land farm assets, summarised in the vector $\mathbf{k}$. Shifter variables $\mathbf{x}$ include household characteristics and village variables. Homogeneity of degree zero of the profit function in prices and capital costs can be imposed by defining a normalised profit function with respect to the prices of an omitted variable input, in this case other variable inputs. Doubling of all prices in the system simultaneously then leaves total normalised profits and all input allocations unchanged. The normalised profit function $\pi$ is written as:

$$
\pi=\prod(\mathbf{p}, \mathbf{w}, \mathbf{k}, \mathbf{x})
$$

After taking the first derivative of the profit function with respect to output prices, input prices and the vector of the shifters gives the output supply function:

\footnotetext{
10 These variable profits are not the same as net profits used for other types of analyses. For example, net profits in cost of cultivation studies (that are used in India to guide the government procurement prices) subtract the opportunity cost of family labour and of capital. Or the analysis of the farm-size-productivity needs to subtract the opportunity cost of family labour, as decisions to rent in or rent out land take account of that opportunity cost (Foster and Rosenzweig, 2011).
} 
$\frac{\partial \pi}{\partial p}=\mathrm{y}(\mathbf{p}, \mathbf{w}, \mathbf{k}, \mathbf{x})$

The demand equation for input variables:

$\frac{\partial \pi}{\partial w}=-\mathrm{d}(\mathbf{p}, \mathbf{w}, \mathbf{k}, \mathbf{x})$

and the equation of return to land owned and non-land farm assets:

$\frac{\partial \pi}{\partial \mathrm{k}}=\mathrm{r}(\mathbf{p}, \mathbf{w}, \mathbf{k}, \mathbf{x})$

Equation (4) cannot be estimated because the values of $r$, the returns to land owned, labour force and non-land farm assets are not known.

\subsection{Quasi-fixed factors: Household labour force, land owned and non-land farm assets ${ }^{11}$}

Because we observed the farms over an 8-year period, we can also estimate the response of quasi-fixed factors to the same variables already included in equation (2). The household could make investments in land, increase or decrease its labour force or invest in non-land farm assets. This provides an opportunity to analyse a longer response of supply to prices and quasi-fixed factors in equation (2). However, it is unlikely to be a true long-run response of the quasi-fixed factors, which would have to be estimated using an investment model that takes into account all of the prices in the intervening years. Based on these prices, farmers would form a desired capital stock to which the actual capital stocks adjust. Adjustments of the capital stock or labour force to the desired stocks at new price levels may be slow for a number of reasons, but especially because of credit constraints for capital and slow responses of migration or changes in labour force due to demographic changes. The responses of the quasi-fixed factors may, therefore, be considered as a medium-term response.

\footnotetext{
${ }^{11}$ The decision to invest in quasi-fixed factors depends on total expected future income. While decisions about variable factors depends on the expected annual income.
} 
In a two period analysis, it is not possible to analyse the structure of the investment decisions. Therefore, we use reduced form equations to analyse the net changes in capital stocks and the labour force as follows:

$$
k_{i}=\mathrm{a}\left(\mathbf{p}, \mathbf{w}, \boldsymbol{k}_{\boldsymbol{j} \neq \boldsymbol{i}}, \mathbf{x}\right)
$$

where $k_{i}$ is one of the three capital stocks and $\boldsymbol{k}_{\boldsymbol{j} \neq \boldsymbol{i}}$ are the other two that enter on the right hand side. The households invest more in land and agricultural assets when agricultural prices are higher. On the other hand, the household may invest less in non-land farm assets when agricultural wages are higher (because this reduces farm profits) and when the rural non-farm wage is higher. Moreover, these decisions are also expected to depend on the urban wage that, for given rural wages, might affect migration. Therefore, for these equations, the vector $\mathbf{W}$ includes the agricultural wage, the rural non-farm wage and the urban wage. Land owned may respond positively to a larger household labour force and, conversely, the labour force may respond positively to the land owned. Land owned may also respond to prices and shifter variables, not in the aggregate, but for individual households. Finally, if a household splits between survey rounds, the descendent households are likely to own less land, at least initially. The equations account for household splits, and include predicted value of household split in the vector $\mathbf{x}$ for households that have split between the two rounds.

\subsection{Short- and medium-term elasticities}

The short-run elasticities estimated in the output supply and input demand equations consider only the responses of output and the variable inputs to changes in prices, wages and the fertiliser price, while the medium-term responses include the responses via changes in the quasi-fixed factors. Estimating both the output and variable input responses, as well as the responses of the quasi-fixed factors, enables the estimation of both the short-term and the medium term elasticities of supply and input demand. The medium term elasticities include the responses to prices of output and variable factors via the changes that the price changes trigger in the levels of the quasi-fixed factors. We consider the elasticities of the quasi-fixed factors as a medium-term response rather than a long-term response because it is unlikely that over the period of eight 
years covered in the study the quasi-fixed factors would have fully adjusted to the price and wage changes.

Let $b_{i j}$ be the elasticity of variable $i$ with respect to the variable $j$. And let $b_{i j}^{*}$ be the respective long-run elasticity that takes into account the impact of variable $j$ on the quasi-fixed factors. Output is $y$, its price is $p$, the labour force is $r$, the land owned is $l$, and the non-land farm assets is $k$. Then, given:

$b_{y p}^{*}=b_{y p}+b_{y l} b_{l p}+b_{y r} b_{r p}+b_{y k} b_{k p}$

and similarly for all the other medium-term elasticities. Because $b_{l p}$ and $b_{r p}$ turned out to be zero, the first and second term dropped out, with only investments in non-land farm assets differentiating short- and medium-term elasticities

A key question of this paper is the size of the elasticity of output with respect to a rise in the national wage level, $\mathrm{d} \Omega$, which corresponds to an equi-proportional rise in the two rural wages and the urban wage. Let $w$ be the hired labour wage, $s$ the non-farm wage, and $u$ the urban wage. The short-run elasticity of output with respect to the national wage level is $b_{y \Omega}=b_{y w}+b_{y s}$, the sum of the hired and the family labour elasticities.

\section{Estimation Strategy}

We have panel data from the 1999 and 2007 rounds of the REDS survey of NCAER for thousands of households across India. To control for fixed household and village effects, we estimate all equations in their first difference form. Let lower case variables stand for the difference in any variable between the 2007 and the 1999 round. We chose the framework of a 
normalised quadratic profit function for this enquiry. ${ }^{12}$ Let $\pi$ stand for the difference between profits in the two years, and $\boldsymbol{q}$ is the column vector of differences in right-hand side variables, so that $\boldsymbol{q}=(\mathrm{p}, \mathrm{w}, \mathrm{k}, \mathrm{x})$, where the notation is as before. In matrix form then the profit function is written as follows:

$\pi=a_{0}+a^{\prime} \boldsymbol{q}+\frac{1}{2} \boldsymbol{q}^{\prime} B \boldsymbol{q}+\varepsilon$

subject to the following constraints:

$b_{i j}=b_{j i} \quad \forall i \neq j$.

Convexity of the profit function in prices is tested by checking whether the submatrix of B corresponding to the square and interaction terms is negative semi-definite. Homogeneity of degree zero in all prices is imposed by the normalisation of the profit function. If some prices are missing, they may of course vary independently of those included. That will create unexplained variation, but not invalidate the homogeneity constraint across the included inputs. For the normalised quadratic profit function, symmetry of the cross price terms can be imposed globally.

Let $\boldsymbol{x}$ be the vector of first derivatives that includes all four variable factors, fertiliser, hired and machine rentals. Output enters this equation as a positive quantity, while all variable inputs enter as a negative quantity.

$x=a+\beta^{\prime} q+\varepsilon$

where $\beta$ is the column of coefficients of the variables, $\alpha$ becomes the time trend for each equation, and $\varepsilon$ the error term. Because we use fixed-effects regression we assume that the

\footnotetext{
${ }^{12}$ Compared to the Translog function, the advantage of using the normalised quadratic function is that symmetry constraints can be imposed globally. Note that both the Translog and the normalised quadratic are almost ideal indexes, as Diewert $(1973,1977)$ showed long ago.
} 
remaining error term is normally distributed with identical variance. In the output supply equation, $\alpha$ is an estimate of the output increase associated with all variation that results from variables not included in the regression, including technical change that is not embodied in the non-land capital and high yielding varieties. The three equations for the quasi-fixed factors are also included in the system (8), and the whole system is estimated using 3SLS.

\subsection{Endogeneity issues}

To overcome issues of unobserved or unobservable variables we applied the fixed-effects technique. ${ }^{13}$ The endogeneity issue arose because over eight years, both the variable allocations and the quasi-fixed factors responded to prices and to exogenous shifter variables. Two solutions were applied: (i) Output prices received by a household may depend on its own actions in terms of choice of quality of the product it produces. Hence we replaced household prices with village prices (computed excluding the price observation of the household), which can be considered as exogenous to the household. Similarly, household farm and non-farm wages were replaced by the village wages; ${ }^{14}$ (ii) We used an instrumental variable approach to first predict the quasifixed factors and then use the predicted values in the output supply and input demand equations of the variable allocation equations. The instrumental variables must influence the quasi-fixed factors, but not the variable allocations.

The identification restrictions imposed on the system are as follows: The urban wage is assumed to influence the size of the household, but not investment in land and non-land capital. For owned land we used the inherited land as the instrument. Predicted household splits enter both the land and the non-farm capital equation. If a household split between the two periods, its

\footnotetext{
${ }^{13}$ The random effects model could not be used because the critical assumption of random effects is that the unobserved individual effects are not correlated with the regressors in the model (Green, 2008). This assumption cannot hold in our case for variables such as education.

${ }^{14}$ This also solves the problem of some households not having any wage or hired worker observations. However it does not solve the limited dependent variable bias in the hired labour demand equation.
} 
quasi-fixed factors would have declined. The probability of such splits between 1999 and 2007 was $19.1 \%$. However, the timings of household splits were also household decision variables and cannot be considered exogenous. Foster and Rosenzweig (2002) predicted the probability of a household split between the 1982 and the 1999 rounds of the ARIS-REDS using a variety of household characteristics that would make them prone to split. To predict the household splits between 1999 and 2007, we used a similar approach, with the estimated equation included in the

online Appendix. ${ }^{15}$ A similar argument can be made for the labour force and total non-land farm assets that were also split up at the time of inheritance. ${ }^{16}$ In addition, the urban wage was used to identify the household labour equation, as it did not affect directly the farm decisions made by the household, urban wage only affected the labour force.

\subsection{Limitations}

As emphasised by Binswanger and Rosenzweig (1986), Binswanger et al. (1993), and Foster and Rosenzweig (2010, 2011), rural credit markets are highly imperfect: how much a household can borrow depends on its characteristics, credit history, how much it has already borrowed, and the amount of land and other assets owned that can be used as collateral or serve as a collateral substitute. Credit is rationed specifically to each household. In addition, household labour has a supervision cost advantage. The opportunity costs of capital and labour vary across households, depending on their labour force and variables that determine borrowing ability, such as land owned that can be used as collateral or as a collateral substitute, and the prior credit history. In

\footnotetext{
${ }^{15}$ The variables included are the head's age and age squared, land owned, mean, maximum and variance of household schooling, number of male and female children, income growth in 1999-2007, total number of claimants, number of departed married daughters, and number of departed sons.

${ }^{16}$ It would have been nice to use the household splits as an instrument for all three variables, but the estimation process of the 2SLS system did not converge. Based on endogeneity tests, we included household splits in the labour force and the non-land farm capital equation, but used inherited land directly as the instrument for the land equations.
} 
equations (1) to (4) the opportunity cost of labour varies across households, but in our analysis, we have taken it to respond to village wages. However, the inclusion of non-land assets makes the credit or cash constraint highly relevant for the farmer's behaviour in somewhat unexpected ways.

Barnum and Squire (1979) and Singh et al. (1986) have emphasised that production decisions are likely to be affected by consumption decisions of the household, rather than to be separable decisions. However, in the data used here, on average, the households allocated only $42 \%$ of their labour force to agriculture, with the remainder in non-agriculture and education (computed from Table 1). When such a large share of labour is allocated to non-farm activities it is more likely that the separability constraint is broadly satisfied. Systems estimates including the nonland farm asset equation could not be estimated, and that equation was therefore estimated outside of the system, using predicted variables for land and the labour force that came from the first stage of the systems estimates.

\section{Econometric Results}

\subsection{Short- and medium-term elasticities of crop output and variable inputs}

Table 3 reports the responses of the quasi-fixed factors to output prices and wages, as well as other right hand side variables, while Table 4 reports output supply and variable input demand elasticities. ${ }^{17}$ As reported in Table 4, we find that the aggregate estimated crop supply elasticity is 0.15 , well within the range of aggregate crop supply elasticities that in the literature range from 0.05 to 0.3 (Binswanger, 1989). ${ }^{18}$ In the short run the extra output is produced by raising all variable inputs with elasticities ranging from 0.04 for rented machines to 0.12 for hired labour and fertiliser. Hired labour appears to be more responsive to the output price than family labour,

\footnotetext{
${ }^{17}$ In the normalised quadratic equation the coefficients are estimates of the elasticities if the variables are all normalised by their mean, which was done. It holds only at the means.

${ }^{18}$ There has been very little work been done on aggregate agricultural supply since 1989.
} 
but the difference is not statistically significant. ${ }^{19}$ Increases in non-land assets also lead to a significant increase in output, with elasticity of 0.74 .

Medium-term elasticities are computed according to equation (6) and summarised, along with the short-run elasticities in Table 5. Because the elasticities of the household labour force and owned land ${ }^{20}$ with respect to prices and wages are zero (Table 3), it is only the response of nonland assets that influences the medium-term elasticities. Taking this into account raises the medium-term output price elasticity to 0.33 . This is close to the long-term elasticity of 0.30 found by Krishna (1982), using a Nerlovian approach with national data.

\footnotetext{
${ }^{19}$ Test for differences is not significant with $p$-value 0.59

${ }^{20}$ The elasticities of owned land with respect to prices and wages has to be zero because the land frontier in India is closed.
} 
Table 3

Estimates of elasticities of quasi fixed factors of production

\begin{tabular}{|c|c|c|c|}
\hline \multirow[b]{2}{*}{ Variables } & \multicolumn{3}{|c|}{ Quasi fixed factor } \\
\hline & $\begin{array}{c}(1) \\
\text { Labour force }\end{array}$ & $\begin{array}{l}(2) \\
\text { Land }\end{array}$ & $\begin{array}{c}(3) \\
\text { Non-land assets }\end{array}$ \\
\hline Output price & $\begin{array}{c}0.003 \\
(0.032)\end{array}$ & $\begin{array}{c}-0.032 \\
(0.034)\end{array}$ & $\begin{array}{l}0.242 * * * \\
(0.071)\end{array}$ \\
\hline Agriculture wage & $\begin{array}{c}-0.032 \\
(0.040)\end{array}$ & & $\begin{array}{c}0.153 \\
(0.127)\end{array}$ \\
\hline Non-agriculture wage & $\begin{array}{c}0.026 \\
(0.034)\end{array}$ & & $\begin{array}{l}-0.193 * * * \\
(0.053)\end{array}$ \\
\hline Predicted land & $\begin{array}{l}0.121 * * * \\
(0.021)\end{array}$ & & $\begin{array}{l}0.238 * * * \\
(0.070)\end{array}$ \\
\hline Gender of the head & $\begin{array}{l}-0.060 \\
(0.042)\end{array}$ & $\begin{array}{c}0.014 \\
(0.045)\end{array}$ & $\begin{array}{l}-0.491 * * * \\
(0.146)\end{array}$ \\
\hline Age of the head & $\begin{array}{l}0.185^{* * * *} \\
(0.043)\end{array}$ & $\begin{array}{l}0.256^{* * * *} \\
(0.044)\end{array}$ & $\begin{array}{l}0.372 * * \\
(0.153)\end{array}$ \\
\hline Education of labour force & $\begin{array}{l}0.383 * * * \\
(0.017)\end{array}$ & $\begin{array}{c}-0.019 \\
(0.020)\end{array}$ & $\begin{array}{l}-0.049 \\
(0.065)\end{array}$ \\
\hline No. of tractors & $\begin{array}{c}0.015 \\
(0.013)\end{array}$ & & $\begin{array}{c}0.062 \\
(0.048)\end{array}$ \\
\hline Panchayat welfare expenditure & $\begin{array}{l}-0.001 \\
(0.002)\end{array}$ & & $\begin{array}{c}0.004 \\
(0.008)\end{array}$ \\
\hline Predicted household split & $\begin{array}{l}-0.304 * * * \\
(0.023)\end{array}$ & & $\begin{array}{l}-0.334 * * * \\
(0.079)\end{array}$ \\
\hline Share of HYV area & $\begin{array}{c}0.022 \\
(0.019)\end{array}$ & $\begin{array}{c}0.021 \\
(0.020)\end{array}$ & $\begin{array}{c}0.016 \\
(0.065)\end{array}$ \\
\hline Predicted labour force & & $\begin{array}{l}0.076 * * * \\
(0.023)\end{array}$ & $\begin{array}{l}0.431 * * * \\
(0.064)\end{array}$ \\
\hline Inherited land & & $\begin{array}{l}0.542 * * * \\
(0.012)\end{array}$ & \\
\hline Fertiliser price & & & $\begin{array}{l}-0.052 \\
(0.049)\end{array}$ \\
\hline Machine rental rate & & & $\begin{array}{l}-0.090 * * \\
(0.035)\end{array}$ \\
\hline Price of non-land farm assets & & & $\begin{array}{l}-0.498 * * * \\
(0.107)\end{array}$ \\
\hline Urban wage & $\begin{array}{c}0.012 \\
(0.069)\end{array}$ & & \\
\hline Constant & $\begin{array}{l}-0.797 * * * \\
(0.045)\end{array}$ & $\begin{array}{l}-0.162 * * * \\
(0.016)\end{array}$ & $\begin{array}{l}0.594 * * * \\
(0.223)\end{array}$ \\
\hline Observations & 2,944 & 2,944 & 2,944 \\
\hline R-squared & 0.245 & 0.461 & 0.074 \\
\hline
\end{tabular}

Notes: Robust standard errors in parentheses. 
Table 4

Estimates of output supply and variable input demand elasticities

\begin{tabular}{|c|c|c|c|c|c|}
\hline \multirow[b]{2}{*}{ Variables } & \multicolumn{5}{|c|}{ Output and variable inputs } \\
\hline & $\begin{array}{c}(1) \\
\text { Output }\end{array}$ & $\begin{array}{c}(2) \\
\text { Hired labour }\end{array}$ & $\begin{array}{c}\text { (3) } \\
\text { Family } \\
\text { labour } \\
\text { (flow) }\end{array}$ & $\begin{array}{c}\text { (4) } \\
\text { Fertiliser }\end{array}$ & $\begin{array}{c}\text { (5) } \\
\text { Machine } \\
\text { rental }\end{array}$ \\
\hline Output price & $\begin{array}{l}0.151 * * * \\
(0.047)\end{array}$ & $\begin{array}{l}0.121^{* * *} \\
(0.046)\end{array}$ & $\begin{array}{l}0.085 * * \\
(0.039)\end{array}$ & $\begin{array}{l}0.123 * * * \\
(0.019)\end{array}$ & $\begin{array}{c}0.037 * * * \\
(0.014)\end{array}$ \\
\hline Agriculture wage & $\begin{array}{c}-0.121 * * * \\
(0.046)\end{array}$ & $\begin{array}{l}-0.490 * * * \\
(0.094)\end{array}$ & $\begin{array}{c}0.064 \\
(0.055)\end{array}$ & $\begin{array}{l}0.134 * * * \\
(0.032)\end{array}$ & $\begin{array}{c}-0.063 * * * \\
(0.024)\end{array}$ \\
\hline Nonfarm wage & $\begin{array}{l}-0.085^{* *} \\
(0.039)\end{array}$ & $\begin{array}{c}0.064 \\
(0.055)\end{array}$ & $\begin{array}{l}-0.433 * * * \\
(0.064)\end{array}$ & $\begin{array}{l}0.290 * * * \\
(0.024)\end{array}$ & $\begin{array}{c}0.044 * * \\
(0.018)\end{array}$ \\
\hline Fertiliser price & $\begin{array}{c}-0.123 * * * \\
(0.019)\end{array}$ & $\begin{array}{l}0.134 * * * \\
(0.032)\end{array}$ & $\begin{array}{l}0.290 * * * \\
(0.024)\end{array}$ & $\begin{array}{c}-0.530 * * * \\
(0.036)\end{array}$ & $\begin{array}{c}-0.117 * * * \\
(0.024)\end{array}$ \\
\hline Machine rental rate & $\begin{array}{c}-0.037 * * * \\
(0.014)\end{array}$ & $\begin{array}{l}-0.063 * * * \\
(0.024)\end{array}$ & $\begin{array}{l}0.044 * * \\
(0.018)\end{array}$ & $\begin{array}{c}-0.117 * * * \\
(0.024)\end{array}$ & $\begin{array}{c}-0.170^{* *} \\
(0.068)\end{array}$ \\
\hline Predicted land & $\begin{array}{c}-0.337 * * * \\
(0.041)\end{array}$ & $\begin{array}{l}-0.188^{* * * *} \\
(0.069)\end{array}$ & $\begin{array}{l}-0.683 * * * \\
(0.053)\end{array}$ & $\begin{array}{c}-0.231 * * * \\
(0.071)\end{array}$ & $\begin{array}{c}1.086 * * * \\
(0.187)\end{array}$ \\
\hline Predicted labour force & $\begin{array}{l}0.451 * * * \\
(0.085)\end{array}$ & $\begin{array}{l}-0.660 * * * \\
(0.140)\end{array}$ & $\begin{array}{l}0.177 * \\
(0.107)\end{array}$ & $\begin{array}{c}-0.524 * * * \\
(0.138)\end{array}$ & $\begin{array}{c}0.045 \\
(0.363)\end{array}$ \\
\hline $\begin{array}{l}\text { Predicted non land } \\
\text { assets }\end{array}$ & $0.741 * * *$ & $0.359 *$ & $0.358 * *$ & $0.448 * *$ & $-1.078 * *$ \\
\hline & $(0.112)$ & $(0.183)$ & $(0.141)$ & $(0.178)$ & $(0.464)$ \\
\hline $\begin{array}{l}\text { Education of labour } \\
\text { force }\end{array}$ & $0.157 * * *$ & $0.226 * * *$ & 0.057 & $0.264 * * *$ & 0.149 \\
\hline & $(0.032)$ & $(0.054)$ & $(0.040)$ & $(0.056)$ & $(0.150)$ \\
\hline Gender of the head & $\begin{array}{l}0.322 * * * \\
(0.079)\end{array}$ & $\begin{array}{c}0.251^{*} \\
(0.132)\end{array}$ & $\begin{array}{c}0.022 \\
(0.099)\end{array}$ & $\begin{array}{c}0.129 \\
(0.138)\end{array}$ & $\begin{array}{l}-0.460 \\
(0.366)\end{array}$ \\
\hline Age of the head & $\begin{array}{c}-0.238 * * * \\
(0.076)\end{array}$ & $\begin{array}{c}0.005 \\
(0.129)\end{array}$ & $\begin{array}{l}-0.220 * * \\
(0.097)\end{array}$ & $\begin{array}{l}-0.150 \\
(0.135)\end{array}$ & $\begin{array}{c}0.343 \\
(0.358)\end{array}$ \\
\hline No of tractors & $\begin{array}{c}0.011 \\
(0.020)\end{array}$ & $\begin{array}{l}-0.020 \\
(0.034)\end{array}$ & $\begin{array}{c}-0.148 * * * \\
(0.025)\end{array}$ & $\begin{array}{l}0.180 * * * \\
(0.036)\end{array}$ & $\begin{array}{c}0.480 * * * \\
(0.097)\end{array}$ \\
\hline Share of HYV area & $\begin{array}{l}0.128 * * * \\
(0.026)\end{array}$ & $\begin{array}{c}0.008 \\
(0.044)\end{array}$ & $\begin{array}{l}0.195 * * * \\
(0.033)\end{array}$ & $\begin{array}{l}0.313 * * * \\
(0.048)\end{array}$ & $\begin{array}{c}0.688 * * * \\
(0.127)\end{array}$ \\
\hline No of village shocks & $\begin{array}{c}-0.084 * * * \\
(0.022)\end{array}$ & $\begin{array}{l}-0.040 \\
(0.038)\end{array}$ & $\begin{array}{l}-0.026 \\
(0.028)\end{array}$ & $\begin{array}{c}-0.115^{* * * *} \\
(0.040)\end{array}$ & $\begin{array}{c}-0.256^{* *} \\
(0.108)\end{array}$ \\
\hline Constant & $\begin{array}{c}-0.389 * * * \\
(0.073)\end{array}$ & $\begin{array}{c}0.063 \\
(0.123)\end{array}$ & $\begin{array}{c}-0.175^{*} \\
(0.092)\end{array}$ & $\begin{array}{c}-0.774 * * * \\
(0.125)\end{array}$ & $\begin{array}{c}1.723 * * * \\
(0.328)\end{array}$ \\
\hline Observations & 2,944 & 2,944 & 2,944 & 2,944 & 2,944 \\
\hline R-squared & 0.040 & 0.039 & 0.273 & 0.110 & 0.036 \\
\hline
\end{tabular}


Since we estimate the agricultural and rural non-farm wage at the village level, the state urban wage is exogenous. In online Appendix Table A2, we find that the urban wage has a strong impact on the aggregate rural wage with elasticity of 0.37 . Both rises in the agricultural and the non-farm wage reduce output in the short term, with elasticities of -0.12 and $-0.09 .^{21}$ To compensate in the short run for any negative agricultural wage effect on output, given the output supply elasticity of 0.15 , would require an increase of the output price by $80 \%$ of the rise in wages. That is an unattractive option because it would be harmful to net consumers, many of whom are poor. The short-term elasticity of output with respect to the non-farm wage is also negative at -0.08 . Since the cross-elasticity between hired and family labour is zero, the elasticity of output with respect to a rise in the wage level is the sum of the two wage elasticities, i.e. -0.21 . This means that, according to these results, an even higher compensatory price increase of $140 \%$ would be required.

However, the impact of price policy on crop output is better considered using the medium elasticities (equation (6)), shown in Table 5. The apparent increase in non-land investments when the agricultural wage rises means that the resulting capital investment partially compensates for the negative output effect of the wage rate rise, and the medium term in the elasticity of output with respect to wages reduces to 0.01 (Table 5). However, given the lack of significance of the investment elasticity with respect to the agricultural wage, though not with the non-farm wage (Table 3 ), there is some uncertainty about this medium-term elasticity. ${ }^{22}$

The elasticity of output with respect to the non-farm wage, on the other hand, reduces non-land investments with a statistically significant elasticity of -0.19 , and therefore the resulting medium term elasticity rises to -0.23 . The price compensation for a rising non-farm wage required in the medium term therefore reduces to a more favourable 70\%. Combining the impact of the two medium-term wage elasticities leads to an estimate of the medium-term elasticity of -0.24 , and a

\footnotetext{
${ }^{21}$ Test for differences is not significant with $p$-value 0.58

${ }^{22}$ Because the non-land equation was estimated outside the system, we unfortunately cannot calculate standard errors about the medium-term elasticities.
} 
resulting compensatory price increase of $73 \% .^{23}$ Notwithstanding the uncertainty about the medium-term elasticity of output with respect to the agricultural wage, it is safe to conclude that the compensation for a wage level rise in the short run is very high at $140 \%$, but that in the medium term it is very likely to be significantly lower, in the neighbourhood of $70 \%$.

Higher wages also affect the composition of the variable inputs used (Table 4). A higher agricultural wage leads to a large decline in the use of hired labour with an elasticity of -0.49 . This is close to the estimate of Evenson and Binswanger (1984), who used a panel of farm group averages from the Studies in the Economics of Farm Management datasets. A higher non-farm wage leads to a similar reduction in family labour applied to agriculture with a lower elasticity of -0.43. Family and hired labour are seen to be very different inputs, as the cross elasticities between their respective quantities and wages are both zero. This implies that the rural labour market is segmented, with farm workers not being able to respond to a rise in the non-farm wage by moving to the non-farm sector, while family labour is able to do so. This finding is consistent with Himanshu and Shariff (2004) who found that it is mainly young male workers with some education who participate in the non-farm sector. Older male workers and women of any age can join the non-farm sector only with great difficulty.

Both the wage rises are partially compensated for by the application of more fertilisers, especially if non-farm wage increases, with an elasticity of 0.29 , more than twice the elasticity of fertilisers with respect to the agricultural wage. ${ }^{24}$ The greater non-farm wage would lead to an increase in the income of the agricultural households, which may relax cash constraints on the household, enabling them to buy more fertiliser. On the other hand, an increase in the agricultural wage reduces the agricultural income and aggravates the cash constraint, and therefore the rise in fertiliser use would be much smaller than in the case of a rise in the nonfarm wage. These findings are therefore consistent with a household cash constraint.

\footnotetext{
${ }^{23}$ Taking the results into account that neither the family labour force nor owned land respond to any of the wage rates, and non-land capital does not respond to the urban wage, the medium-term elasticity with respect to $\Omega$ can be estimated as follows: $b_{y \Omega}^{*}=b_{y \Omega}+b_{y k}\left(b_{k w}+b_{k s}\right)$.

${ }^{24}$ Test for differences is highly significant with the Chi2 statistic at 14.46.
} 
A higher agricultural wage should normally lead to a substitution of rented machines for labour, ${ }^{25}$ but this wage elasticity is negative and significant, at -0.06 in the short run and -0.09 in the medium term. This result is unexpected. However, it could again be consistent with farmers being cash constrained and having to cut machine hire to offset the higher labour costs. On the other hand, in the short run, machine rentals rise when the non-farm wage increases with an elasticity of 0.04 , which is an expected effect of the reallocation of family labour to the non-farm sector.

Machine hire responds negatively to investments in non-land assets with one of the largest elasticities found in the paper of -1.08 . There are two routes: The increase in owned machines that are contained in non-land assets allows for a reduction in machine hire, and the shift to greater investment into animals (that are also contained in non-land assets), reduces machine rental because animals such as milk cows are mainly tended by family labour that cannot be substituted by machines. ${ }^{26}$

The remaining elasticities of interest relate to the responses of non-land farm assets to prices of output and variable inputs, and the responses of non-land assets to the two wages, which are responses that arise in the medium term. The highest elasticity is that of output with respect to non-land assets, at 0.70 , while machine hire responds with an elasticity of -1.08 , probably because non-land assets include machines. The other noteworthy aspect is the contrast between the elasticity of non-land assets with respect to the agricultural and non-farm wages (0.15 to 0.19 respectively), where the latter probably reflects the shift of assets out of agriculture to the non-farm sector in response to higher payoffs there.

While there is little surprise about the supply and labour demand elasticities, and therefore the unattractiveness of raising prices in response to higher wages, the separate treatment of hired and family labour leads to some unexpected results. This arises both because the cross-elasticities

\footnotetext{
${ }^{25}$ Few farmers own their own machines, but rely on rented tractors and other machinery.

${ }^{26}$ That would change with the introduction of milking machines, but these were not common in 2007.
} 
between hired and family labour on the one hand and the agricultural and non-farm wage on the other hand is zero, suggesting that these two types of labour are different. That is consistent with the supervision cost of hired labour that does not arise in the case of family labour (Binswanger and Rosenzweig, 1986). It is also consistent with the higher ease of young male family workers to shift to the non-farm sector than that of landless workers. Finally, the segmentation may also arise because a rise in hired labour costs increases the cash constraint on farm households, while an increase in the non-farm wage reduces it.

Table 5

The key elasticities: Short and medium term

\begin{tabular}{lcc}
\hline Elasticities & $\begin{array}{c}\text { Short } \\
\text { term }\end{array}$ & $\begin{array}{c}\text { Medium } \\
\text { term }^{\mathbf{a}}\end{array}$ \\
\hline Output with respect to its price & +0.15 & +0.33 \\
Output with respect to agricultural wage & -0.12 & -0.01 \\
Output with respect to non-farm wage & -0.09 & -0.23 \\
Output with respect to the rural wage & -0.21 & -0.24 \\
Output with respect to fertiliser price & -0.12 & -0.15 \\
Output with respect to machine rental rate & -0.04 & -0.10 \\
Hired labour with respect to agricultural wage & -0.49 & -0.43 \\
Family labour with respect to non-farm wage & -0.43 & -0.50 \\
Machine rental with respect to agricultural wage & -0.06 & -0.09 \\
Machine rental with respect to non-farm wage & +0.04 & +0.14 \\
Output with respect to non-land farm assets & & +0.74 \\
Non-land assets with respect to agricultural wage & & +0.15 \\
Non-land assets with respect to non-farm wage & & -0.19 \\
Hired labour with respect to non-land assets & & +0.36 \\
Family labour with respect to non-land assets & & +0.36 \\
Machine rental with respect to non-land assets & & -1.08 \\
\hline
\end{tabular}

Notes: All elasticities are statistically significant. a: Calculated according to equation (6).

\subsection{How can Indian Agriculture deal with rising wages?}

In Table 6 the medium-term elasticities of output with respect to the independent variables is repeated and multiplied by the observed growth rate in the respective variable to compute the growth contribution of the variable to output. The actual growth rate in crop output was $1.17 \%$ per annum. The modest rise in the agricultural wage rate alone would have had virtually no impact on crop output in the short and medium term. The much larger rise in the non-farm wage would have reduced output $-0.49 \%$ in the medium term, and therefore what happens to non-farm 
wages may be more important for agricultural policy than what happens to the agricultural wage itself.

Among the quasi-fixed factors, non-land farm assets and the labour force have the highest elasticities with respect to output, at 0.74 and 0.49 , respectively. ${ }^{27}$ These estimated elasticities appear to be very high. The education of the labour force and the coverage of HYV have elasticities of 0.16 and 0.13 , respectively, while tractors have no impact on output, consistent with Binswanger (1978) and (1986). Embodied technical change is included in non-land assets, the education of the labour force, the village tractor stock and high yielding varieties. Moreover, the shift in the supply curve over the period of 1999 to 2007 is negative 0.39, which is almost 5\% per year. A negative intercept means that the entire output supply curve has shifted downwards or outwards, which means that at any given price more output can be produced at the same price and with no more input. The sign is therefore as we should have expected. The estimated annual rate of productivity growth due to disembodied technical change, however, is very high.

Except for tractors, all the shifter variables made positive contributions to agricultural output growth, of which the most significant is from the rapid rise in non-land farm assets at $4.74 \%$. Contributions in the order of $0.5 \%$ were also made by the increase in the household labour force and its average level of education. Clearly during the period of investigation, rising wages were no threat to agricultural output growth. Gulati et al. (2014) published a farm wage series from 1991 to 2011 based on observed wages for five farm operations that accounted for 93\% of the hired labour input in Indian agriculture. The period under our consideration (1999-2007) was one of slow agricultural growth and it experienced a growth rate in farm wages at $0.90 \%$ per annum. For the period 2008-2011 at the annual rate agricultural wage growth was $10 \%$. However, if in the second period the non-farm wage had also increased at the rate of $10 \%{ }^{28}$ it would have reduced output by $2.1 \%$ in the short run and $2.3 \%$ in the medium term. Whether the

\footnotetext{
${ }^{27}$ An increase in owned land reduces crop output per acre with an elasticity of -0.34 , which is consistent with the negative farm-size productivity relationship. Since the availability of agricultural land in India stopped increasing long ago, this coefficient is not considered in the subsequent analysis.

${ }^{28}$ Data on changes in the non-farm wage are not available.
} 
changes in the output price and the shifters (non-land agricultural capital, human capital, the labour force, disembodied technical change and structural change) would have been enough to restore the loss from the rising wages needs to be explored in future research. ${ }^{29}$

Table 6

Elasticities, growth rates and growth contributions

\begin{tabular}{lccc}
\hline Variable- & $\begin{array}{c}\text { Medium term } \\
\text { elasticity of } \\
\text { output with } \\
\text { respect to }\end{array}$ & $\begin{array}{c}\text { 1999-2007 } \\
\text { (REDS) }\end{array}$ & rnual growth \\
rate & $\begin{array}{c}\text { Growth } \\
\text { contribution }\end{array}$ \\
\hline Output & Na & $\mathbf{1 . 1 7}$ & $\mathbf{1 . 1 7}$ \\
Output price & 0.33 & 1.48 & \\
Agricultural wage & -0.01 & 0.90 & -0.01 \\
Non-farm wage & -0.23 & 2.16 & -0.49 \\
Fertiliser price & -0.15 & -0.60 & 0.09 \\
Machine rental rate & -0.10 & 2.43 & -0.24 \\
Labour force & 0.48 & 1.17 & 0.56 \\
Education of labour force & 0.16 & 3.28 & 0.52 \\
Non-land farm assets & 0.74 & 6.40 & 4.74 \\
Tractors in village & 0.00 & 2.34 & 0.00 \\
Village HYV rate & 0.13 & 1.20 & 0.16 \\
\hline
\end{tabular}

\section{Summary and Conclusions}

The application of the variable profit function framework with quasi-fixed factors to Indian agriculture generated a number of expected results. The aggregate crop output supply elasticity with respect to its price is 0.15 in the short term and 0.33 in the medium turn, with the rise being a consequence of the significant response of non-land farm assets to the output price. These estimates are in line with other estimates of short- and long-run output supply elasticities from national or district level data in India, and the same is the case for the fertiliser demand elasticity.

\footnotetext{
${ }^{29}$ The reason is that data on investment into non-land farm assets and on the non-farm wage are only available for the period under investigation from the ARIS-REDS, but not from secondary data.
} 
For the demand for hired labour, the estimated elasticity is also close to estimates that used panels of groups of households from the Studies in the Economics of Farm Management datasets. These similarities suggest that data aggregation problems may not be a serious source of bias in coefficients when more aggregated data are used for the estimation of response elasticities in Indian agriculture.

We observe a rapid response of agriculture to higher wages in terms of mechanisation via the machine rental market. Rising farm wages lead to a reduction in the use of hired workers, but not family workers. Conversely rising non-farm wages pull family workers, but not hired workers, out of farming. The agricultural markets for hired and family workers are therefore segmented, a conclusion that is reinforced by the zero cross elasticity of hired and family labour with respect to the non-farm and the farm wage, respectively. The results also suggest that some of the income gains of the family members are spent on fertiliser and on machine hire. Farmers also greatly accelerated their investment in non-land farm assets with large impacts on crop output. Farmers also diversified rapidly to higher valued crops and into the rural non-farm economy (Binswanger et al., 2014).

Capturing the segmentation of the markets for hired and family labour enriched our analysis significantly and will have to be taken into account in future studies of the response of the agricultural sector to structural change. There are three reasons for the segmentation: First is the impact of the higher supervision cost of hired labour on the relative attractiveness of hired versus family labour. Second is the fact that family labour, especially young men, can more easily move to non-farm employment than hired workers, many of whom are older and have little education. Third is that rises in these two wage rates have opposite impacts on the cash constraints of farmers, with a rise in the hired wage rate reducing farmer income and increasing the cash constraints, while a rise in the non-farm wage, via the reallocation of family labour to the nonfarm sector, increases non-farm income and reduces the cash constraint. The segmentation of the labour market may be the reason why, during the period of investigation, the agricultural and the non-farm wages changed at rates that differed considerably. Such differences imply that policymakers need to look at both scenarios, one in which the rise in wages is confined to the agricultural wage, and one where the non-farm wage rises at the same rate or vice versa. 
Rises in both the agricultural and the non-farm wages reduce output in the short term, ceteris paribus, with elasticities of -0.12 and $-0.09 .{ }^{30}$ To compensate in the short run for any negative agricultural wage effect on output, given the output supply elasticity of 0.15 , would require an increase of the output price by $80 \%$ of the rise in wages, which is an unattractive policy option. The combined effect of a rise in both wages would require an even higher compensatory price increase of $140 \%$, which is even less attractive. However, in the medium term the higher wage rates affect investments in non-land assets, leading to an output gain that reduces the price increase required to compensate for the rising wages to $74 \%$, still an unattractive policy option.

During the period of 1999-2008, agricultural wages rose by $0.9 \%$ per annum, while the rural non-farm wage rose by $2.3 \%$. Because the estimated medium-term output elasticity with respect to the agricultural wage is low, it is only the rise in the rural non-farm wage that would have affected output negatively by $-0.49 \%$, which would have been aggravated to $-0.73 \%$ on account of the rapid rise in machine rental rates. However, the rapid growth of non-land farm assets alone would have been sufficient to more than offset these negative impacts. ${ }^{31}$ The other farmer adjustments discussed above would also have helped. The growth of household labour and of the education of the labour force also contributed significantly to crop output growth. Whether these changes would have continued into 2011 (when the agricultural wage series ends), and would have been able to compensate for the much higher subsequent growth rate in agricultural wages has yet to be analysed. ${ }^{32}$

Non-land farm assets are the most responsive quasi-fixed factor of production to price and wage changes, and to an increase in family labour. Its increase also had the largest output effect among

\footnotetext{
${ }^{30}$ Test for differences is not significant with $p$-value 0.58 .

${ }^{31}$ Even if the elasticity were overestimated, the impact of non-land farm assets would have been dominant because of the large increase.

32 The reason is that data on investment into non-land farm assets and on the non-farm wage are only available for the period under investigation from the ARIS-REDS, but not from secondary data.
} 
the three quasi-fixed factors. Non-land farm assets are also a strong complement to fertilisers, further boosting the impact of increases in non-land farm assets on crop output. If rapid investment in non-land farm assets continues, there will be little worry about the negative impact of rising rural wages on aggregate crop output. Increasing crop output will help the growth in agricultural incomes that is also being boosted by the diversification of farmers into higher value agricultural products such as horticulture and livestock products, which are not analysed here. The diversification into the rural non-farm sector will help to maintain household income parity, even though it does not contribute to farm income parity. The growing labour force and higher educational achievements of the rural labour force also contributed significantly to output growth. With continued rural population growth, the first will continue to rise for a long time, while the second will also rise because of the recent rapid rise in school attendance of both boys and girls. These findings lead us to be optimistic about the capacity of Indian agriculture to adjust to higher wages that stem from rapid growth and structural transformation without having to resort to policies that increase the aggregate price of crops, and therefore hurt consumers.

\section{References}

Anderson, Kym, ed. Distortions to agricultural incentives: A global perspective, 1955-2007 (Washington D. C.: The World Bank Publications, 2009)

Anderson, Kym, John Cockburn, and Will Martin, eds. Agricultural price distortions, inequality, and poverty (Washington D.C.: The World Bank Publications, 2010)

Barnum, H.N. and Squire, L. A model of an agricultural household: theory and evidence Malaysia (Washington D.C.: Published for the World Bank by Johns Hopkins University Press, 1979)

Binswanger, Hans P. The Economics of Tractors in South Asia: An Analytical Review (New York: The Agricultural Development Council and Hyderabad, India: ICRISAT, 1978)

Binswanger, Hans P. 'Agricultural Mechanization: A Comparative Historical Perspective', The World Bank Research Observer, Vol. 1(1), (1986) pp 27-56.

Binswanger-Mkhize, H.P. 'The Stunted Structural Transformation of the Indian Economy', Economic and Political Weekly, Vol (48), (2013) pp 5-13.

Binswanger, H. P., Mundlak, Y., Yang, M-C. and Bowers, A. 'On the Determinants of Cross Country Aggregate Agricultural Supply', Journal of Econometrics, (36), (1985) pp 111-31. 
Binswanger, H. P. and Rosenzweig, M. R. Behavioural and Material Determinants of Production Relations in Agriculture', The Journal of Development Studies, Vol. 22 (3), (1986) pp 503-539.

Binswanger, H. P. The Policy Response of Agriculture (In S. Fischer and D. de Tray, eds., Proceedings of the World Bank Annual Conference on Development Economics, World Bank, Washington, D.C., 1989)

Binswanger, H. P., Khandker, S. R. and Rosenzweig, M. R. 'How Infrastructure and Financial Institutions Affect Agricultural Output and Investment in India', Journal of Development Economics, 41, (1993) pp.337-366.

Binswanger, H. P., Singh, J.P. and, Singh, S.K. India 1999-2007: Dynamics of Structural Change at the Village and Household Level, RBI Endowment Unit Working Paper Series 06 (Institute of Rural Management Anand, 2014)

Cavallo, D. and Mundlak, Y. Agricultural and Economic Growth in an Open Economy: The case of Argentina, Research report No. 36 (Washington D.C.: International Food Policy Research Institute, 1982)

Chibber, A. The aggregate supply response of agriculture: A survey, (In S.Commander, ed. Structural adjustment and Agriculture, Theory and Practice, London, Jame Curry Publishers, 1988)

Coeymans, J.E., and Mundlak, Y. Sectoral Growth in Chile: 1962-82, Research Report No. 95 (Washington, D.C.: International Food Policy Research Institute, 1993)

Deininger, K., Nagarajan, H.K. and Singh, S.K. Short-term effects of India's employment guarantee program on labor markets and agricultural productivity, Policy Research Working Paper Series 7665 (The World Bank, 2016)

Diewert, W.E. 'Functional forms for profit and transformation functions', Journal of Economic Theory, Vol. 6(3), (1973) pp 284-316.

Diewert, W.E. 'Exact and superlative index numbers', Journal of econometrics, Vol. 4(2), (1976) pp 115145.

Evenson, R. E. and Binswanger, H. P. Estimating Labour Demand Functions in Indian Agriculture (Chapter 13 in Binswanger, Hans P. and Mark R. Rosenzweig, eds. Contractual Arrangements, Employment, and Wages in Rural Labour Markets in Asia. New Haven: Yale University Press, 1984) 
Fan, S., Hazell, P. and Haque, T. 'Targeting public investments by agro-ecological zone to achieve growth and poverty alleviation goals in rural India', Food Policy, 25, (2000) pp 411-428.

Foster, A.D. and Rosenzweig, M.R. 'Household Division, Inequality and Rural Economic Growth', Review of Economic Studies, 69(4), (2002) pp 839-869

Foster, AD and Rosenzweig, M. R. Is there Surplus labour in Rural India, Working Paper No. 85 (Yale University, Department of Economics, 2010)

Foster, A. D., and Rosenzweig, M. R. Are Indian Farms Too Small? Mechanization, Agency Costs, and Farm Efficiency, Unpublished Manuscript (Brown University and Yale University, 2011).

Available online at: http://economics.yale.edu/sites/default/files/files/Workshops-

$\underline{\text { Seminars/Development/rosenzweig-111114.pdf (last accessed: April } 10 \text { 2016) }}$

Greene, W.H. The econometric approach to efficiency analysis: The measurement of productive efficiency and productivity growth, (2008), pp 92-250.

Gulati, A., Jain, S. and Satija, N. 'Rising Farm Wages in India-The 'Pull' and 'Push' Factors', Journal of Land and Rural Studies, Vol. 2(2), (2014) pp 261-286.

Imbert, C. and Papp, J. 'Labor market effects of social programs: Evidence from india's employment guarantee', American Economic Journal: Applied Economics, 7(2), (2015) pp 233-263

Jacoby, H.G. 'Food prices, wages, and welfare in rural India', Economic Inquiry, 54(1), (2016) pp 159176.

Krihna, R. 'Some Aspects of Agricultural Growth Price Policy and Equity in Developing Countries', Food Research Institute Studies (US), Vol. 18 (3), 1982 pp 219-60.

Lanjouw, P. and Shariff, A. 'Rural Non-Farm Employment in India: Access, Incomes and Poverty Impact', Economic and Political Weekly, 39(40), 2004 pp 4429-46.

Mc Guirk, A. and Mundlak, Y. Incentives and Constraints in the Transformation of Indian Agriculture, Research Report No. 87 (Washington D.C.: International Food Policy Research Institute, 1991)

Mundlak, Y. Agriculture and Economic Growth: Theory and measurement (Cambridge, Mass: Harvard University Press, 2000)

Mundlak, Y., Cavallo, D. and Domenech, R. Agricultural and Economic Growth, Argentina 1913-84, Research Report No. 76 (Washington, D.C.: International Food Policy Research Institute, 1988) 
Otsuka, K, Liu, Y. and Yamauchi F. 'Factor Endowments, Wage Growth and Changing Food Selfsufficiency: Evidence from Country-Level Panel Data', American Journal of Agricultural Economics, 95(5), (2013) pp 1252-1258.

Peterson, W.L. 'International farm prices and the social cost of cheap food policies', American Journal of Agricultural Economics, 61(1), (1979) pp 12-21

Rao, Mohan J. ‘Agricultural Supply Response: A Survey', Agricultural Economics, 3(1), (1989) pp 1-22

Reca, Argentina: Country Case of Study of Agricultural Prices and Subsidies, Staff Working Paper No. 386 (Washington, D.C.: The World Bank Publications, 1976)

Singh, I., Squire, L. and Strauss, J. Agricultural household models: Extensions, applications, and policy (Washington D.C.: The World Bank Publications, 1986)

Timmer, C Peter A World without Agriculture: The Structural Transformation in Historical Perspective (Washington D.C.: American Enterprise Institute, 2009)

Wang, X., Yamauchi, F., Otsuka, K. and Huang, J. 'Wage growth, landholding, and mechanization in Chinese agriculture', World Development, 86, (2016) pp 30-45.

Wang, X., Yamauchi, F. and Huang, J. 'Rising wages, mechanization, and the substitution between capital and labor: evidence from small scale farm system in China', Agricultural Economics, 47(3), (2016) pp 309-317.

Yamauchi, F. 'Rising real wages, mechanization and growing advantage of large farms: Evidence from Indonesia', Food Policy, 58, (2016) pp 62-69. 


\section{Appendix}

Table A1

Estimates of household split between 1999 and 2007 using REDS data

\begin{tabular}{lc}
\hline & $(1)$ \\
Variables & Household \\
& split \\
\hline Head's age & $0.036^{* *}$ \\
& $(0.014)$ \\
Head's age squared & $-0.000^{* *}$ \\
& $(0.000)$ \\
Land owned & 0.203 \\
Mean schooling & $(0.310)$ \\
Maximum schooling & -0.017 \\
& $(0.027)$ \\
Variance in schooling & -0.013 \\
& $(0.020)$ \\
No. of male children & -0.002 \\
& $(0.007)$ \\
No. of female children & $0.106^{* * *}$ \\
Income growth, 1999-2007 & $(0.022)$ \\
Income growth x mean schooling & 0.033 \\
Income growth x max schooling & $(0.024)$ \\
Income growth x variance in schooling & -0.185 \\
Total no. of claimants & $(0.470)$ \\
No. of departed married daughters & $0.417 * *$ \\
No. of departed sons & $(0.179)$ \\
Constant & $-0.389^{* * *}$ \\
Observations & $(0.138)$ \\
Var & 0.050 \\
& $(0.053)$ \\
& -0.010 \\
& $(0.021)$ \\
& -0.028 \\
& $(0.031)$ \\
& $0.153^{* * *}$ \\
& $(0.030)$ \\
& $-2.047 * * *$ \\
& $(0.366)$ \\
& 2,944 \\
\hline
\end{tabular}

Note: Variables used to predict household split are from REDS 1999 survey round. For more details see Foster and Rosenzweig (2002). Standard errors in parentheses $* * * p<0.01, * * p<0.05, * p<0.1$ 
Table A2

Correlates of rural wage

\begin{tabular}{|c|c|}
\hline Variables & $\begin{array}{c}(1) \\
\text { Rural } \\
\text { wage }\end{array}$ \\
\hline Output price & $\begin{array}{c}-0.007 \\
(0.036)\end{array}$ \\
\hline No. of tractors & $\begin{array}{c}0.040^{*} \\
(0.020)\end{array}$ \\
\hline Urban wage & $\begin{array}{l}0.370 * * \\
(0.140)\end{array}$ \\
\hline Panchayat welfare expenditure & $\begin{array}{c}0.001 \\
(0.005)\end{array}$ \\
\hline Fertiliser price & $\begin{array}{c}-0.038 \\
(0.040)\end{array}$ \\
\hline Share of HYV area & $\begin{array}{c}-0.029 \\
(0.040)\end{array}$ \\
\hline Asset's price index & $\begin{array}{c}-0.114^{*} \\
(0.056)\end{array}$ \\
\hline No. of village shocks & $\begin{array}{c}0.031 \\
(0.024)\end{array}$ \\
\hline Constant & $\begin{array}{l}0.202 * * \\
(0.088)\end{array}$ \\
\hline $\begin{array}{l}\text { Observations } \\
\text { R-squared }\end{array}$ & $\begin{array}{l}2,944 \\
0.104\end{array}$ \\
\hline
\end{tabular}

Note: All variables used are at village level except Urban wage. Standard errors in parentheses. *** $p<0.01, * * p<0.05, * p<0.1$ 